\title{
Faktor-Faktor yang Memengaruhi Pengalaman dan Kepuasan Pelanggan Perkotaan dalam Pembelian Melalui M-commerce
}

\author{
Margaretha Pink Berlianto \\ ${ }^{1}$ Program Studi Manajemen, Universitas Pelita Harapan \\ Tangerang, Banten 15811, Indonesia \\ margaretha.berlianto@uph.edu
}

Received 31 August 2020, Revised 28 September 2020, Accepted 29 September 2020

\begin{abstract}
This study aims to investigate the factors influencing urban customer experience and satisfaction in mobile commerce (m-commerce). Population of this study are customer of $m$ commerce Shopee in Jakarta. Data are collected from 188 respondents. PLS SEM in used to analyze the collected data and test the research hypothesis. The result of this study indicate that service quality is strongly linked to customer experience and customer satisfaction. Service quality have a positive effect on customer experience and customer satisfaction, perceived risk have a negative effect on customer satisfaction and customer experience has a posititve effect on customer satisfaction. Practical implication of this study shows that practioner of $m$-commerce should increase their service quality, reduced the perceived risk of their m-commerce and also increase customer experience in order to make customer satisfied.
\end{abstract}

Keywords: experience, satisfaction, service quality, perceived risk, $m$-commerce

\begin{abstract}
Abstrak - Penelitian ini bertujuan untuk menginvestigasi faktor-faktor yang memengaruhi pengalaman dan kepuasan pelanggan perkotaan pada pembelanjaan melalui perangkat mobile $(\mathrm{m}$ commerce). Penelitian ini mengambil populasi dari pelanggan Shopee yang bertempat tinggal di Jakarta dan pernah melakukan pembelian melalui aplikasi mobile Shopee di telepon genggam atau tablet. Data diambil dari 188 responden. PLS SEM digunakan untuk menganalisis data dan menguji hipotesis penelitian. Hasil penelitian ini adalah kualitas layanan berpengaruh positif terhadap pengalaman dan kepuasan pelanggan, perceived risk berpengaruh negatif terhadap kepuasan pelanggan dan pengalaman pelanggan berpengaruh positif terhadap kepuasan pelanggan. Implikasi praktis dari penelitian ini adalah pelaku bisnis $m$-commerce harus dapat meningkatkan kualitas layanannya, mengurangi perceived risk dari m-commerce yang mereka kelola, dan juga meningkatkan pengalaman pelanggan untuk membuat pelanggan mereka puas.
\end{abstract}

Kata Kunci: pengalaman, kepuasan, kualitas layanan, perceived risk, $m$-commerce

\section{PENDAHULUAN}

Perkembangan internet yang pesat diikuti dengan bertumbuhnya toko online dan belanja online di seluruh dunia termasuk Indonesia. Hal ini membuat perubahaan perilaku demografis konsumen perkotaan. Masyarakat perkotaan menghabiskan waktu rata-rata 3,9 jam untuk browsing, media sosial dan aktivitas digital lainnya (Kompas.com, 2018). Selain perubahan perilaku konsumen perkotaan, pelaku bisnis juga mengambil kesempatan ini untuk melakukan perdagangan via internet yang disebut dengan e-commerce. Peritel online menggunakan internet karena kenyamanannya, biaya yang lebih murah, lebih interaktif dibandingkan dengan toko tradisional, dan tingkat kostumisasi dan personalisasi yang tinggi kepada pelanggannya (Heejun \& Seung, 2007). Dengan berkembangnya teknologi perangkat keras, pelanggan yang dahulu hanya menggunakan komputer untuk bereksplorasi di internet, sekarang juga dapat menggunakan telepon genggam untuk mengakses internet. Hal ini membuat pelaku bisnis $e$ - commerce berekspansi ke platform yang lebih mobile dan lebih mudah bagi pelanggan yaitu dengan membuat sebuah aplikasi di telepon genggam yang disebut juga dengan mobile commerce atau biasa disingkat dengan m-commerce. Berdasarkan data mengenai tren dan prediksi mengenai pasar $m$ commerce tahun 2020-2025 menunjukkan bahwa $49 \%$ konsumen global mengunakan telepon pintar dalam melakukan pembelanjaan dengan total transaksi m-commerce sebesar US\$ 2,3 Trilyun pada tahun 2019. Pendapatan dari sektor m-commerce diprediksi akan menjadi US\$ 3,56 Trilyun pada tahun 2021. Asia Pasifik termasuk Indonesia merupakan wilayah dengan tingkat pertumbuhan yang tinggi. Tingkat konversi pembelian pelanggan karena melakukan pembelanjaan menggunakan smartphones sebesar 41,32\% (Appinventiv, 2020). Angka ini cukup fantastik jika mengingat bahwa tidak ada tenaga penjualan yang digunakan untuk mempersuasi pembeli agar terjadinya konversi pembelian. Menurut Appinventiv (2020), terdapat beberapa alasan 
mengapa sebuah perusahaan harus berinvestasi dalam applikasi m-commerce, yaitu lebih hemat waktu bagi pelanggan dibandingkan dengan toko tradisional, jangkauan yang lebih luas, pilihan pembayaran yang lebih banyak, meningkatkan reputasi merek, dan meningkatnya pengalaman pelanggan.

Alasan diatas, sejalan dengan pernyataan Klaus \& Maklan (2012) yang menyatakan bahwa pengalaman pelanggan merupakan garis terdepan dari kompetisi bisnis modern. Selain itu, pengalaman pelanggan perlu mendapatkan perhatian utama dalam manajemen pemasaran karena memengaruhi kepuasan pelanggan, loyalitas, keuntungan perusahaan (Kumar, Pozza, \& Ganesh, 2013) dan sebagai sumber evaluasi dan pengambilan keputusan (Holbrook \& Hirschman, 1982; Turki \& Amara, 2017). Produk dan layanan saja tidak lagi cukup untuk berkompetisi dalam dunia komoditi yang meningkat saat ini. Perusahaan haruslah bergerak diluar tahap produk dan layanan ke tahap pengalaman pelanggan dan transformasi (Pine II \& Gilmore, 2000). Dengan memberikan pengalaman yang memorable kepada pelanggan, perusahaan dapat berkompetisi dengan pasar dengan lebih baik, membedakan perusahaan dengan kompetitor yang memiliki positioning yang sama, dan mendapatkan loyalitas pelanggan melalui penawaran yang menawan (Levy, Weitz, \& Grewal, 2015). Pengalaman berpengaruh terhadap merek, karena kemampuannya dalam menguatkan hubungan antara pelanggan dan merek (Chaney, Lunardo, \& Mencarelli, 2018).

Konsep pengalaman pelanggan sangatlah penting bagi peritel, baik dalam bentuk brick and press, click and collect dan research online/purchase online. Pelanggan menggunakan fitur-fitur tertentu untuk mengevaluasi kualitas layanan yang disediakan melalui internet ketika membeli barang dari toko online (Tzavlopoulos, Gotzamani, Andronikidis, \& Vassiliadis, 2019). Sebagai konsekuensinya maka sangatlah penting untuk mengidentifikasi faktorfaktor yang dapat memengaruhi pengalaman pelanggan. Penelitian terdahulu menginvestigasi faktor-faktor yang memengaruhi pengalaman pelanggan pada beberapa sektor tertentu, seperti faktor perceived value, kualitas fungsional, kualitas layanan, keterlibatan karyawan-pelanggan, perceived risk, perceived useability pada sektor perbankan digital di UK (Mbama \& Ezepue, 2018), faktor kewajaran harga, kewajaran prosedural, kecukupan hasil dan kewajaran interkasi di industri restoran di Korea Selatan (Kim, Shin, \& Koo, 2018), faktor merchandise, layanan paska transaksi, komunikasi, komunikasi personal, atmosfir toko dan program loyalitas pada industri ritel di Malaysia (Mohd-Ramly \& Omar, 2017) dan dimensi-dimensi kenyaman pada m-shopping di India (Mahapatra, 2017). Penelitian ini befokus pada faktor kualitas layanan dan perceived risk dalam konteks m-commerce pada masyarakat perkotaan, mengingat bahwa masih sedikitnya penelitian mengenai faktor dan pada industri $m$ - commerce. Selain itu, belum adanya konsensus yang sama mengenai pengaruh perceived risk terhadap kepuasan, dimana Poromatikul, De Maeyer, Leelapanyalert, \& Zaby (2020) menemukan bahwa perceived risk tidak berpengaruh terhadap kepuasan pada $m$-banking, sedangkan Chang, Chih, Liou, \& Yang (2016) pada e-commerce dan Chen \& Li (2017) pada layanan pembayaran mobile menemukan bahwa perceived risk berpengaruh negatif terhadap kepuasan. Untuk itu, penelitian ini menginvestigasi faktor-faktor yang memengaruhi pengalaman pelanggan dan kepuasan pelanggan seperti kualitas layanan dan perceived risk pada m-shopping dan pengaruh pengalaman pelanggan terhadap kepuasan pelanggan.

Berdasarkan uraian permasalahan diatas, maka pertanyaan penelitian ini adalah:

1. Apakah kualitas layanan dari m-commerce berpengaruh positif terhadap pengalaman pelanggan masyarakat perkotaan?

2. Apakah kualitas layanan dari m-commerce berpengaruh positif terhadap kepuasan pelanggan masyarakat perkotaan?

3. Apakah perceived risk dari m-commerce berpengaruh negatif terhadap pengalaman pelanggan masyarakat perkotaan?

4. Apakah perceived risk dari m-commerce berpengaruh negatif terhadap kepuasan pelanggan masyarakat perkotaan?

5. Apakah pengalaman pelanggan berpengaruh positif terhadap kepuasan pelanggan masyarakat perkotaan?

Penelitian ini diharapkan dapat memberikan kontribusi mengenai faktor-faktor yang perlu diperhatikan pelaku usaha m-commerce untuk menciptakan pengalaman dan kepuasan pelanggannya dan juga memberikan tambahan literatur dalam hal kualitas layanan, perceived risk, pengalaman dan kepuasan pelanggan.

Terdapat keyakinan konvensional bahwa kelangsungan hidup dan pertumbuhan organisasi tergantung pada kepuasan pelanggan karena memengaruhi penjualan dan keuntungan perusahaan secara langsung (Gustafsson, Johnson, \& Roos, 2005). Kepuasan pelanggan adalah konsep psychologikal yaitu perasaan positif yang dihasilkan dari apa yang diharapkan dari sebuah produk atau layanan (Pizam, Shapoval, \& Ellis, 2016). Kepuasan pelanggan didefinisikan sebagai sikap yang dihasilkan dari perbedaan antara harapan kinerja dan kinerja yang diterima pada pengalaman layanan (Oliver, 1980).

Berdasarkan perspektif pengguna, kualitas layanan adalah standar kinerja yang tinggi yang secara konsisten memenuhi atau bahkan melebihi harapan pelanggan dan mengacu pada sikap dan keyakinan yang relaitf stabil mengenai sebuah perusahaan (Wirtz \& Lovelock, 2018). Kualitas layanan adalah ukuran 
sejauh mana tingkat layanan yang diberikan sesai dengan pengalaman pelanggan (Santos, 2003). Pada penelitian ini, kualitas layanan yang dimaksudkan adalah kualitas layanan dari m-shopping. Kualitas layanan secara online atau disebut juga Automated service quality didefinisikan oleh Santos (2003) sebagai keseluruhan evaluasi dan penilaian pelanggan mengenai keunggulan dan kualitas layanan elektronik yang diberikan melalui virtual market place. Mengukur kualitas layanan merupakan sesuatu yang sulit dikarenakan evaluasi kualitas layanan tidak hanya berdasarkan hasil dari layanan tetapi juga penilaian pada saat proses pemberian layanan (Nguyen, Nisar, Knox, \& Prabhakar, 2018).

Walaupun kualitas layanan dan kepuasan pelanggan merupakan konstruk yang berbeda, namun kepuasan pelanggan dan kualitas layanan ditentukan dengan cara yang sama yaitu dengan membandingkan harapan pelangan dengan persepsi dari kinerja yang diterimanya (Wirtz \& Lovelock, 2018). Kualitas layanan merupakan pendorong penting dan juga prediktor kepuasan pelanggan. Beberapa penelitian sebelumnya seperti Khoo, Ha, \& McGregor (2017) menemukan bahwa kualitas layanan berpengaruh positif terhadap kepuasan di industri pendidikan di Singapura, Boon-itt (2015) di industri online dan mobile banking di Thailand, Lin, Luo, Cai, Ma, \& Rong (2016) pada e-commerce di China, Rajaguru (2016) di industri pariwisata di Singapura dan Roy, Sreejesh, \& Bhatia (2019) pada sektor B2B. Selain ditemukan berpengaruh terhadap kepuasan, kualitas layanan juga ditemukan berpengaruh terhadap pengalaman konsumsi pelanggan (Boo, Lee, \& Murray, 2014; Rahman, Mannan, Hossain, \& Zaman, 2018; Roy et al., 2019; Mbama \& Ezepue, 2018). Dari uraian mengenai literatur penelitian terdahulu yang pernah dilakukan, maka dibentuklah hipotesis sebagai berikut:

H1: Service quality dari m-shopping berpengaruh positif terhadap pengalaman pelanggan masyarakat perkotaan.

$\mathrm{H} 2$ : Service quality dari $m$-shopping berpengaruh positif terhadap kepuasan pelanggan masyarakat perkotaan.

Perceived risk merupakan aspek penting dari perilaku konsumen (Chang \& Tseng, 2013). Semakin sulit untuk mengevaluasi sebuah layanan, maka semakin tinggi perceived risk yang berasosiasi dengan keputusan pembelian (Wirtz \& Lovelock, 2018). Perceived risk adalah ketidakpastian dan konsekuensi potensial yang dapat merugikan karena pembelian produk atau layanan (Littler \& Melanthiou, 2006). Dalam konteks e-commerce atau m-commerce, perceived risk didefinisikan sebagai dugaan konsumen akan kerugian spesifik dan subjektif yang terjadi saat membeli melalui internet (Forsythe \& Shi, 2003). Pada pembelian melalui online, konsumen terpapar resiko yang lebih tinggi dibandingkan dengan pembelian melalu toko fisik karena konsumen akan menghadapi ketidakpastian dalam mencapai tujuan pembelanjaan (Forsythe, Liu, Shannon, \& Gardner, 2006) dan sering kali berpengaruh pada resistansi pelanggan untuk menggunakan teknologi mobile dan online (Laukkanen \& Kiviniemi, 2010). Menurut Chang \& Chen (2008), perceived risk yang berkurang akan meningkatkan peluang pembelian dan penurunan tersebut berguna untuk meningkatkan kepercayaan pelanggan. Perceived risk ditemukan berpengaruh negatif terhadap pengalaman pelanggan (Mbama \& Ezepue, 2018) dan kepuasan pelanggan (Chen \& Li, 2017; Lainamngern \& Sawmong, 2019; Tandon, Kiran, \& Sah, 2018). Menurut Meuter, Ostrom, Bitner, \& Roundtree (2003), perceived risk menciptakan pikiran yang negatif mengenai teknologi baru dan berpengaruh negarif terhadap kepuasan. Berdasarkan uraian diatas, maka:

H3: Perceived risk dari m-shopping berpengaruh negatif terhadap pengalaman pelanggan masyarakat perkotaan.

H4: Perceived risk dari m-shopping berpengaruh negatif terhadap kepuasan pelanggan masyarakat perkotaan.

Pengalaman pelanggan berfokus pada sifat hedonis dan emosional dari konsumsi (Koetz, 2019). Pengalaman adalah pernyataan mental subjektif yang dirasakan oleh partisipan (Otto \& Ritchie, 1996). Pengalaman pelanggan adalah evolusi dari konsep hubungan antara hubungan antara perusahaan dan pelanggan (Gentile, Spiller, \& Noci, 2007). Konsep pengalaman pelanggan merupakan pendekatan experiential yang memberikan pandangan original terhadap perilaku pelanggan (Holbrook \& Hirschman, 1982). Dalam perspektif experiential, pengalaman konsumsi tidak lagi dibatasi pada aktivitas prapembelian dan aktivitas setelah pembelian, tetapi mencakup serangkaian kegiatan lain yang mempengaruhi keputusan dan tindakan konsumen di masa depan (Carù \& Cova, 2003). Menurut Mahapatra (2017), pengalaman konsumsi adalah pengalaman yang diciptakan dalam benak pelanggan, yang pada akhirnya berubah menjadi mengevaluasi, terlibat dalam sebuah tindakan dan menjadi bentuk aktivitas niat konsumsi dimasa yang akan datang. Pada penelitian menggunakan definisi pengalaman konsumsi dari Mahapatra (2017).

Pengalaman pelanggan merupakan respon intenal dan subjektif pelanggan terhadap kontak perusahaan secara langsung maupun tidak langsung dan melewati berbagai aspek penawaran perusahaan, seperti kualitas customer care, iklan, kemasan, produk, dan fitur layanan, kemudahan penggunaan dan keandalan. Kontak langsung pada umumnya terjadi pada pembelian, penggunaan dan layanan yang dimulai dari pelanggan. Sedangkan kontak tidak langsung yaitu pertemuan yang tidak direncanakan dengan perwakilan produk, layanan atau merek dan 
merupakan bentuk dari rekomendasi word of mouth atau kritik, iklan, laporan, review dan lainnya (Meyer \& Schwager, 2007). Respons pelanggan terhadap pengalamannya dapat mencakup komponen kognitif, emosional, perilaku, sensorik, dan sosial, dan mungkin dipicu oleh perusahaan berdasarkan karakteristik produk atau merek atau elemen lain, seperti situs web perusahaan atau aplikasi seluler (Koetz, 2019). Kepuasan adalah evaluasi paska pembelian dari suatu produk atau layanan setelah pengalaman konsumsi (Sharma \& Patterson, 2000) Penelitian sebelumnya menemukan bahwa pengalaman pelanggan berpengaruh positif terhadap kepuasan (Boo et al., 2014; Giannoulakis, Wang, \& Felver, 2015; Roy et al., 2019; Shahijan, Rezaei, \& Amin, 2018; Suhartanto, Brien, Sumarjan, \& Wibisono, 2018; Mbama \& Ezepue, 2018; Trivedi \& Jagani, 2018). Berdasarkan uraian diatas, maka:

H5: Pengalaman pelanggan mengenai $m$-shopping berpengaruh positif terhadap kepuasan pelanggan.

Berdasarkan pengembangan hipotesis diatas, maka dibentuklah model penelitian seperti pada Gambar 1.

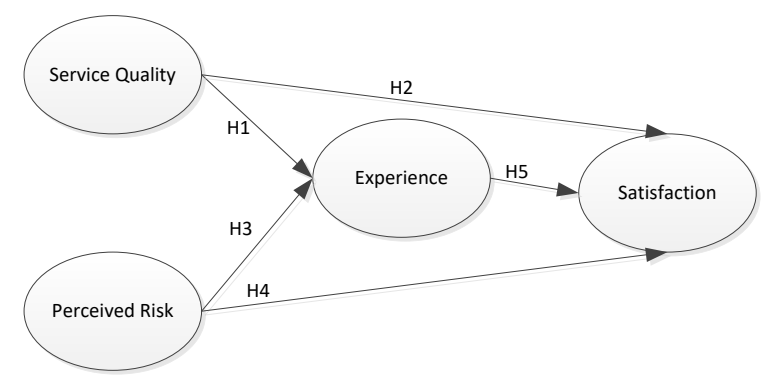

Gambar 1. Rerangka Penelitian

\section{METODE PENELITIAN}

Populasi pada penelitian ini adalah masyarakat di Jakarta yang pernah berbelanja di Shopee melalui aplikasi mobile Shopee. Penelitian ini dilakukan dengan menggunakan data primer dengan cara menyebarkan kuisioner terhadap 200 responden yang berdomisili di Jakarta. Berdasarkan pertimbangan dari Wong (2013) yang menyatakan bahwa 100-200 sampel sudah baik untuk digunakan dala sebuah penelitian. Teknik pengambilan sampel adalah purposive sampling, dengan kriteria individu-individu yang menggunakan $m$-shopping Shopee dan pernah berbelanja lebih dari 1 kali melalui m-shopping Shopee.

Kualitas layanan terdiri atas tiga indikator yang diadopsi dari $\mathrm{Wu}$, (2014). Perceived risk terdiri dari tiga indikator yang diadopsi dari Liao, Lin, \& Liu (2010). Kepuasan terdiri dari tiga indikator yang diadopsi dari Cronin, Brady, \& Hult, (2000). Dan pengalaman pelanggan terdiri dari tiga indikator yang diadopsi dari Mahapatra (2017).

Metode analisis data yang dalam penelitian ini adalah Partial Least Square Strutural Equation
Modeling technique (PLS-SEM). Pengujian outer model evaluation menggunakan indicator reliability dengan nilai standardized indicator loading $>0,70$, internal consistency reliability dengan menggunakan nilai composite reliability $>0,70$, validitas konvergen dengan menggunakan nilai AVE > 0,5 dan validitas diskriminan dengan menggunakan Fornel-Larcker criterion dimana nilai akar kuadarat AVE dari kontruk yang dituju lebih besar dibandingkan dengan nilai akar kuadrat AVE pada konstruk yang lain. Pengujian inner model dilakukan dengan melihat nilai $\mathrm{R}^{2}$ dan estimasi koefisien jalur (Hair, Sarstedt, Ringle, \& Mena, 2012).

Sebelum dilakukan penyebaran kuisioner sebanyak 200 orang, terlebih dahulu dilakukan pretest untuk mengetahui validitas dari indikator yang digunakan dan reliabilitas dari variabel yang ada. Pretest dilakukan dengan menyebarkan 40 kuisioner kepada individu yang tinggal di Jakarta dan pernah berbelanja di Shopee melalui smartphone ataupun gadget. Hasil pretest menunjukkan bahwa semua indikator valid dan semua variabel reliabel sehingga layak untuk dilakukan penyebaran kuisioner aktual.

\section{HASIL PENELITIAN DAN ANALISIS}

Dari 200 kuisioner yang dibagikan terdapat 188 kuisioner layak untuk digunakan dalam penelitian ini dengan tingkat response rate sebesar 94 persen.

\begin{tabular}{|c|c|c|}
\hline Pernyataaan & Total & $\begin{array}{c}\text { Persentase } \\
(\%)\end{array}$ \\
\hline \multicolumn{3}{|l|}{ Jenis Kelamin } \\
\hline Pria & 40 & $21,3 \%$ \\
\hline Wanita & 148 & $78,7 \%$ \\
\hline \multicolumn{3}{|l|}{ Pekerjaan: } \\
\hline Pelajar/Mahasiswa & 171 & $91,0 \%$ \\
\hline Karyawan & 15 & $8,0 \%$ \\
\hline Lainnya & 2 & $1,0 \%$ \\
\hline \multicolumn{3}{|l|}{ Usia } \\
\hline 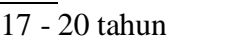 & 152 & $80,9 \%$ \\
\hline 21- 30 tahun & 33 & $17,5 \%$ \\
\hline $31-40$ tahun & 1 & $0,5 \%$ \\
\hline$>41$ tahun & 2 & $1,1 \%$ \\
\hline \multicolumn{3}{|c|}{ Frekuensi berbelanja di m- } \\
\hline \multicolumn{3}{|c|}{ Shopee dalam 3 bulan terakhir } \\
\hline 1 kali & 17 & $9,1 \%$ \\
\hline 2 kali & 25 & $13,3 \%$ \\
\hline 3 kali & 20 & $10,6 \%$ \\
\hline 4 kali & 91 & $48,4 \%$ \\
\hline$>4$ kali & 35 & $18,6 \%$ \\
\hline
\end{tabular}

Tabel 1 merupakan hasil dari profil responden pada penelitian ini. Terdapat 40 responden pria $(21,3$ persen) dan 148 responden wanita ( 78,7 persen) pada penelitian ini. Pelajar sebanyak 171 orang $(91,0$ persen), 15 orang bekerja sebagai karyawan $(8,0$ persen) dan pekerjaan lainnya sebanyak 2 orang $(1,0$ persen). Usia responden 17-20 tahun sebanyak 152 
orang (80,9 persen), 21-30 tahun sebanyak 33 orang (17,5 persen), 31-40 tahun sebanyak 1 orang $(0,5$ persen) dan diatas 41 tahun sebanyak 2 orang $(1,1$ persen). Frekuensi responden berbelanja di m-Shopee selama 6 bulan terakhir adalah 17 orang sebanyak 1 kali (9,1 persen), 25 orang sebanyak 2 kali $(13,3$ persen), 20 orang sebanyak $3 x$ (10,6 persen), 91 orang sebanyak 4 kali (48,4 persen) dan 35 orang sebanyak lebih dari 4 kali (18,6 persen).

Pengujian model pengukuran (Outer Model Evaluation) pada penelitian ini dilakukan dengan pengecekan indicator reliability, internal consistency reliability, validitas konvergen, dan validitas deskriminan. Indicator reliability dapat dilihat dari pada tabel 2 dimana dapat dilihat bahwa semua nilai masing-masing indicator loadings diatas 0,7 sehingga memiliki nilai yang baik. Pada pengujian internal consistency reliability dapat dilihat bahwa nilai composite reliability dari masing-masing variabel yang ada adalah diatas 0,7 sehingga dapat dikatakan reliabel. Kemudian dilakukan pengujian validitas konvergen, dimana nilai AVE diatas 0,5 (Tabel 2), sehingga dinyatakan valid.

Tabel 3 merupakan hasil pengujian validitas deskriminan, dimana nilai validitas deskriminan pada penelitian ini adalah baik, dikarenakan nilai akar kuadarat AVE dari variabel yang dituju lebih besar dibandingkan dengan nilai akar kuadrat AVE pada variabel yang lain.
Tabel 2. Hasil Measurement Model

\begin{tabular}{|c|c|}
\hline Variabel \& item & $\begin{array}{c}\text { Outer } \\
\text { Loading }\end{array}$ \\
\hline \multicolumn{2}{|c|}{ Kualitas layanan $(C R=0,927, A V E=0,808)$} \\
\hline SQ1 & 0,889 \\
\hline SQ2 & 0,921 \\
\hline SQ3 & 0,886 \\
\hline \multicolumn{2}{|c|}{ Perceived Risk $(\boldsymbol{C R}=\mathbf{0 , 9 4 6 ,} \boldsymbol{A} \boldsymbol{V E}=\mathbf{0 , 8 5 3})$} \\
\hline PR1 & 0,925 \\
\hline PR2 & 0,925 \\
\hline PR3 & 0,921 \\
\hline \multicolumn{2}{|c|}{ Kepuasan $(C R=0,933, A V E=0,822)$} \\
\hline SAT1 & 0,924 \\
\hline SAT2 & 0,887 \\
\hline SAT3 & 0,910 \\
\hline \multicolumn{2}{|c|}{ Pengalaman pelanggan $(C R=0,933, A V E=0,824)$} \\
\hline CE1 & 0,930 \\
\hline CE2 & 0,905 \\
\hline CE3 & 0,887 \\
\hline
\end{tabular}

Keterangan: $C R=$ Composite Reliability; $A V E=$ average variance extracted.

Sumber: Hasil pengolahan data PLS (2020)

Tabel 3. Validitas Diskriminan

\begin{tabular}{ccccc}
\hline & CE & PR & SQ & CS \\
\hline CE & $\mathbf{0 , 9 0 8}$ & & & \\
PR & $-0,190$ & $\mathbf{0 , 9 2 4}$ & & \\
SQ & 0,569 & $-0,287$ & $\mathbf{0 , 8 9 9}$ & \\
CS & 0,545 & $-0,454$ & 0,659 & $\mathbf{0 , 9 0 7}$ \\
\hline
\end{tabular}

Ket: $\mathrm{CE}=$ Experience, $\mathrm{PR}=$ Perceived Risk, $\mathrm{SQ}=$ Kualitas Layanan, $\mathrm{CS}=$ kepuasan.

Sumber: Hasil pengolahan data PLS (2020)

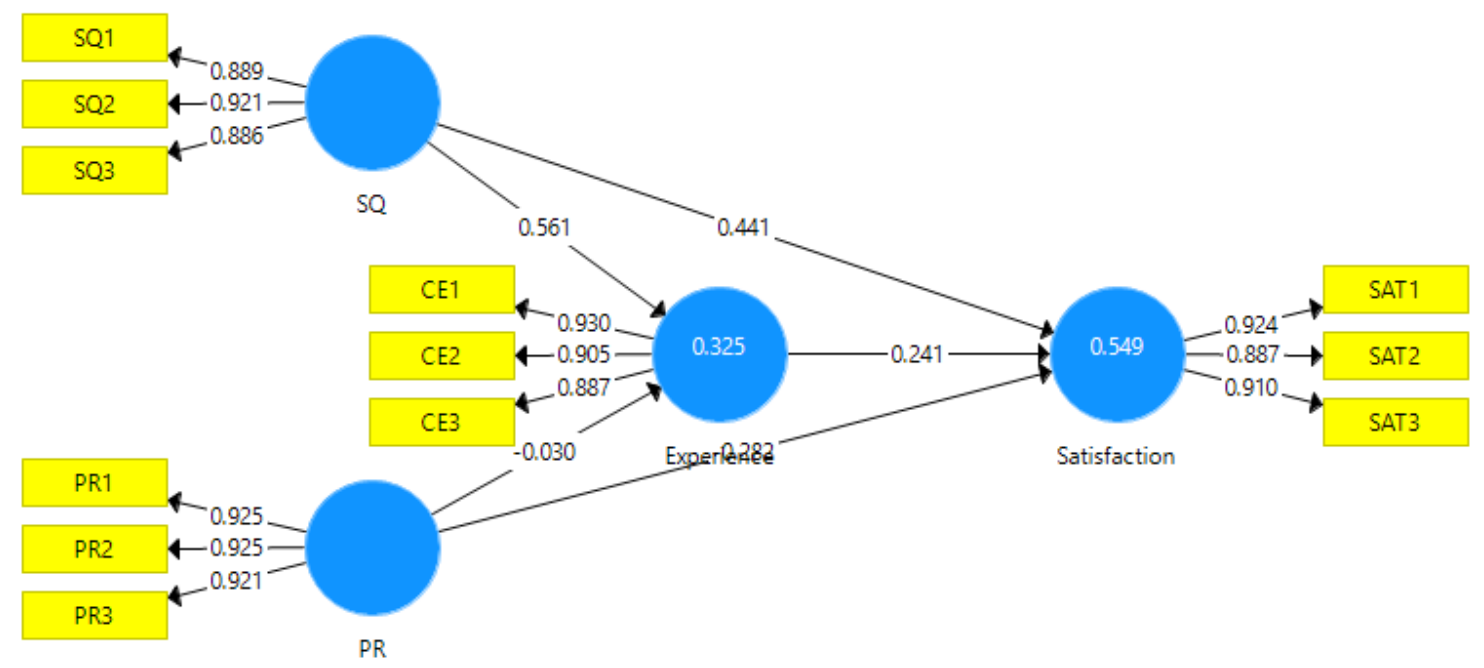

Gambar 2. Measurement Model Path

Setelah dilakukan pengujian outer model dan semua threshold validitas dan reliabilitas terpenuhi, maka selanjutnya dilakukan pengujian inner model. Untuk melakukan pengecekan apakah terdapat masalah multicollinearity maka dilakukan uji collinearity statistic. Hal ini disebabkan karena informasi mengenai sebuah indikator bisa menjadi redundan karena tingkat multicollinearity yang tinggi dimana dapat menyebabkan indikator-indikator menjadi tidak signifikan (Hair, Ringle, \& Sarstedt, 2011). Tabel 4 menunjukkan nilai variance inflation factor (VIF) antara 1,090 - 1,555 atau dibawah 5 
sehingga tidak terjadi multicollinearity pada penelitain ini.

Tabel 4. Collinearity Statistics (VIF)

\begin{tabular}{ccc}
\hline & Pengalaman & Kepuasan \\
\hline Pengalaman & - & 1,481 \\
Perceived risk & 1,090 & 1,091 \\
Kualitas & 1,090 & 1,555 \\
layanan & & \\
\hline
\end{tabular}

Sumber: Hasil pengolahan data PLS (2020)

Selanjutnya dilakukan pengujian $\mathrm{R}^{2}$. Tabel 6 menunjukkan bahwa nilai $r$-square pengalaman pelanggan adalah 0,325 yaitu lemah. Hal ini berarti bahwa pengaruh kualitas layanan dan perceived risk terhadap pengalaman pelanggan COO sebesar 32,5 persen, dimana sisanya 67,5 persen dipengaruhi oleh variabel lain diluar dari penelitian ini. Nilai $r$-square kualitas layanan, perceived risk dan pengalaman pelanggan terhadap kepuasan adalah sebesar 54,9 persen yaitu memiliki pengaruh moderat, dimana sisanya 45,1 persen dipengaruhi oleh konstruk lain diluar dari penelitian ini.

Tabel 5. Hasil Uji R-Square

\begin{tabular}{cc}
\hline Variabel & Nilai $\boldsymbol{r}$ Square \\
\hline Pengalaman pelanggan & 0,325 \\
Kepuasan & 0.549 \\
\hline Sumber: Hasil pengolahan data dengan PLS (2020)
\end{tabular}

Selanjutnyan dilakukan pengujian signifikansi koefisien jalur dengan melakukan bootstrapping 5000 sampel dengan kriterai $t$-value untuk one tail adalah > 1,65 dan p-value <0,5 dengan tingkat keyakinan $95 \%$. Dari lima hipotesis yang diuji, terdapat empat hipotesis yang diterima dan satu hipotesis yang tidak didukung karena memiliki nilai t-statistik $<1,65$ (Tabel 6), yaitu perceived risk tidak berpengaruh terhadap pengalaman pelanggan $(\mathrm{H} 3)$.

Tabel 6. Hasil Uji Hipotesis

\begin{tabular}{|c|c|c|c|c|}
\hline $\mathbf{H}$ & Jalur & $\begin{array}{c}\text { Original } \\
\text { sample }\end{array}$ & $\begin{array}{c}\mathrm{t}- \\
\text { statistik }\end{array}$ & Hasil \\
\hline $\mathrm{H}_{1}$ & $\begin{array}{l}\text { Kualitas } \\
\text { layanan } \rightarrow \\
\text { pengalaman }\end{array}$ & 0,561 & 8,712 & Didukung \\
\hline $\mathrm{H}_{2}$ & $\begin{array}{l}\text { Kualitas } \\
\text { layanan } \rightarrow \\
\text { kepuasan }\end{array}$ & 0,441 & 5,041 & Didukung \\
\hline $\mathrm{H}_{3}$ & $\begin{array}{l}\text { Perceived } \\
\text { Risk } \rightarrow \\
\text { pengalaman }\end{array}$ & $-0,030$ & 0,497 & $\begin{array}{c}\text { Tidak } \\
\text { didukung }\end{array}$ \\
\hline $\mathrm{H}_{4}$ & $\begin{array}{l}\text { Perceived } \\
\text { Risk } \rightarrow \\
\text { kepuasan }\end{array}$ & $-0,282$ & 3,811 & Didukung \\
\hline $\mathrm{H}_{5}$ & $\begin{array}{l}\text { Pengalaman } \\
\rightarrow \text { kepuasan }\end{array}$ & 0,241 & 4,499 & Didukung \\
\hline
\end{tabular}

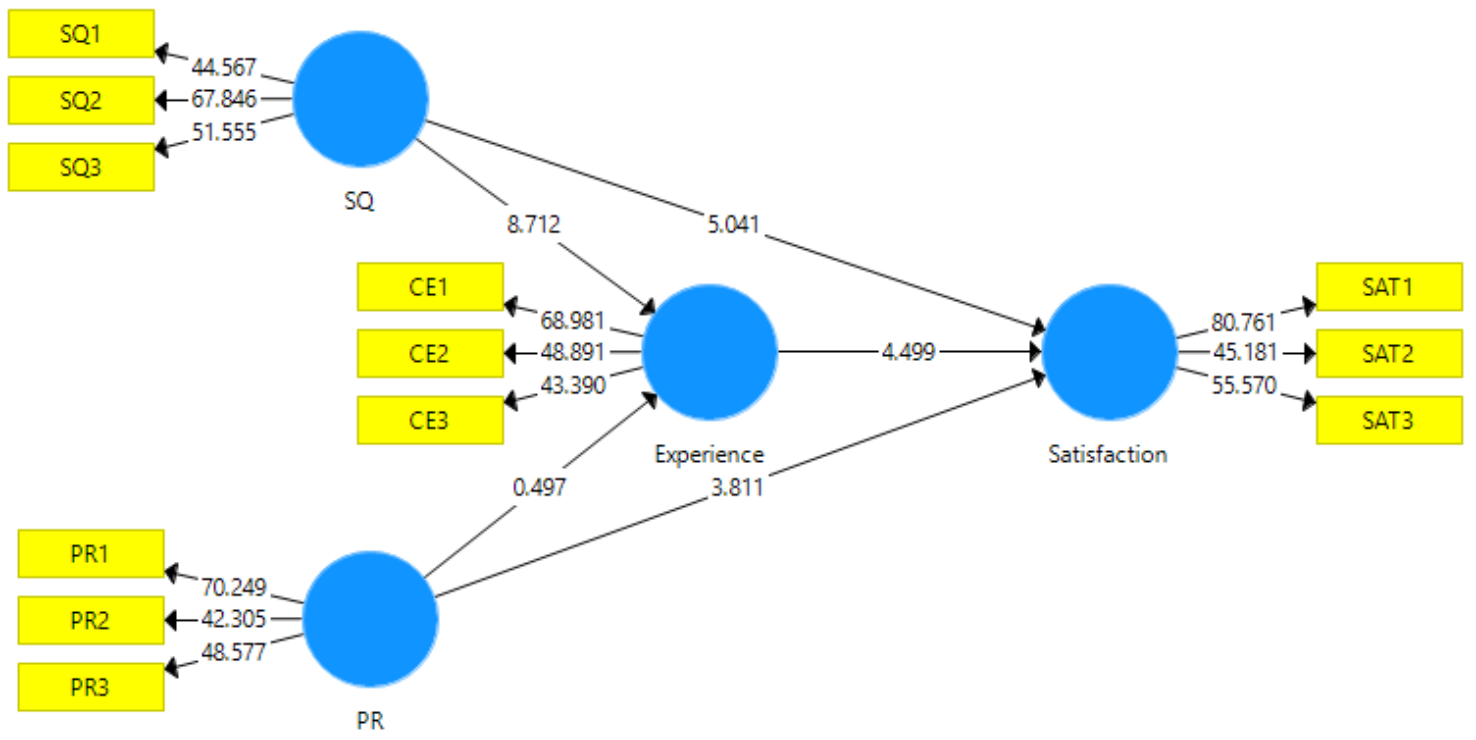

Gambar 3. Model Struktural

Tabel 7 menunjukkan pengaruh tidak langsung atau efek mediasi dari variebel eksogen dan endogen. Pengalaman pelanggan ditemukan sebagai memediasi antara kualitas layanan dan kepuasan (t-value $=4,172$, one tailed, $\mathrm{p}$-value $<0,5)$. Akan tetapi pengalaman pelanggan tidak ditemukan sebagai mediasi antara perceived risk dan kepuasan ( $\mathrm{t}$-value $<1,65$, one tailed, p-value >0,5). 
Tabel 7. Pengaruh Tidak Langsung

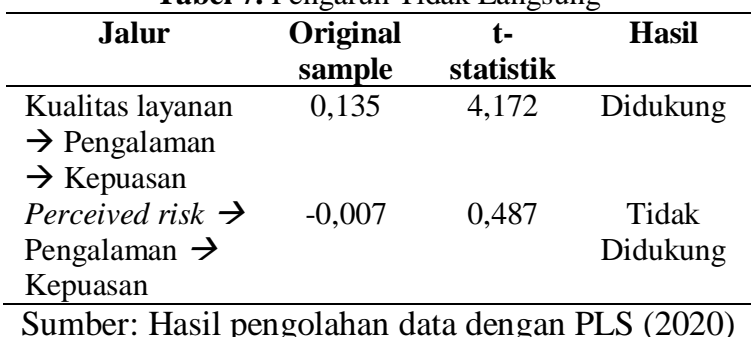

\section{Diskusi}

Penelitian ini bertujuan untuk memberikan masukan kepada manajer dan pelaku bisnis yang bergerak dalam bidang $m$-commerce mengenai faktorfaktor yang memengaruhi pengalaman dan kepuasan pelanggan perkotaan. Penelitian ini berhasil menunjukkan bahwa kualitas layanan berpengaruh positif terhadap pengalaman dan kepuasan pelanggan, perceived risk negatif berpengaruh terhadap kepuasan pelanggan dan pengalaman pelanggan berpengaruh positif terhadap kepuasan pelanggan. Hasil $\mathrm{H} 1$ pada penelitian menunjukkan bahwa kualitas layanan berpengaruh positif terhadap pengalaman pelanggan (t-statistik $=8,712>1,65 ; p$-value $<0,05)$. Hal ini berarti bahwa semakin tinggi kualitas layanan yang diberikan oleh m-shopping maka semakin tinggi pengalaman pelanggan. Kualitas layanan $m$ commerce yang baik akan memengaruhi pengalaman pelanggan. Hasil penelitian ini mendukung hasil penelitian sebelumnya (Boo et al., 2014; Rahman et al., 2018; Roy et al., 2019; Mbama \& Ezepue, 2018).

Hasil H2 menunjukkan bahwa kualitas layanan berpengaruh positif terhadap kepuasan pelanggan $(\mathrm{t}-$ statistik $=5,041>1,65 ;$-value $<0,05)$. Hal ini berarti bahwa semakin tinggi kualitas layanan yang diberikan oleh m-commerce maka semakin tinggi kepuasan pelangan. Kualitas layanan m-commerce yang baik akan memengaruhi kepuasan pelanggan. Hasil penelitian ini mendukung hasil penelitian sebelumnya (Boon-itt, 2015; Khoo et al., 2017; Rajaguru, 2016; Roy et al., 2019). Hipotesis tiga menyatakan bahwa perceived risk berpengaruh negatif terhadap pengalaman pelanggan. Hasil penelitian tidak mendukung H3 (t-statistik = 0,497 $<1,65 ;$ p-value $<$ $0,05)$. Hal ini berarti bahwa resiko yang dirasakan tidak berpengaruh terhadap pengalaman pelanggan. Hasil ini menunjukkan bahwa perceived risk yang ada terkait dengan $m$-commerce tidak akan memengaruhi pengalaman pelanggan terhadap m-commerce tersebut. Ini berarti bahwa pelanggan perkotaan sudah menyadari resiko-resiko yang terkait dengan pembelanjaan online dan walaupun memiliki resiko, hal tersebut tidak memengaruhi pengalaman belanja mereka. Hasil ini cukup menggembirakan bagi pelaku bisnis $m$-commerce karena mereka berhasil menekan perceived risk yang ada sehingga tidak memberikan dampak yang signifikan terhadap pengalaman belanja pelanggan. Hasil $\mathrm{H} 4$ menemukan bahwa perceived risk berpengaruh negatif terhadap kepuasan pelanggan (t-statistik $=3,811>1,65 ;$-value $<0,05$ ).
Hal ini berarti bahwa semakin tinggi perceived risk maka semakin rendah kepuasan pelanggan dan sebaliknya. Hasil penelitian ini mendukung hasil penelitian sebelumnya (Chen \& Li, 2017; Lainamngern \& Sawmong, 2019; Tandon et al., 2018). Hasil H5 menemukan bahwa pengalaman pelanggan berpengaruh positif terhadap kepuasan pelanggan (t-statistik $=4,499>1,65 ;$-value $<0,05$ ). Hal ini berarti bahwa semakin tinggi pengalaman pelanggan maka semakin tinggi kepuasan pelanggan dan sebaliknya. Pengalaman belanja online yang baik akan meningkatkan kepuasan pelanggan. Hasil penelitian ini mendukung hasil penelitian sebelumnya (Boo et al., 2014; Giannoulakis et al., 2015; Roy et al., 2019; Shahijan et al., 2018; Suhartanto et al., 2018).

\section{KESIMPULAN}

Berdasarkan hasil analisa dan pengolahan data, maka beberapa kesimpulan yang dapat ditarik dalam penelitian ini adalah kualitas layanan berpengaruh positif terhadap pengalaman dan kepuasan pelanggan, pengalaman pelanggan berpengaruh positif terhadap kepuasan, dan perceived risk tidak berpengaruh terhadap pengalaman pelanggan tetapi berpengaruh negatif terhadap kepuasan. Penemuan ini menunjukkan bahwa resiko yang dirasakan oleh pelanggan perkotaan ketika berbelanja online tidak akan memengaruhi pengalaman berbelanja mereka karena pada umumnya masyarakat perkotaan telah menyadari, terbiasa untuk melakukan pembelanjaan online dan juga dapat mengukur resiko yang ada ketika berbelanja secara online. Hal tersebut dapat dilihat bahwa lebih dari 90,9\% responden pernah berbelanja online lebih dari satu kali. Berbelanja secara online merupakan salah satu alternatif aktivitas pembelian yang biasa digunakan oleh masyarakat perkotaan selain offline. Perceived risk yang ada hanya memengaruhi kepuasan pelanggan perkotaan, yang berarti bahwa semakin tinggi resiko dalam pembelian online yang dirasakan pelanggan maka akan mengurangi kepuasan belanja mereka dimana hal ini didukung oleh penelitan-penelitian sebelumnya (Chen \& Li, 2017; Lainamngern \& Sawmong, 2019; Tandon et al., 2018).

Implikasi teoritis penelitian ini adalah penelitian ini berhasil mendukung penelitian terdahulu dan menambah referensi terkini mengenai pengaruh kualitas layanan terhadap pengalaman dan kepuasan pelanggan, pengaruh perceived risk terhadap kepuasan pelanggan dan pengaruh pengalaman pelanggan terhadap kepuasan pelanggan, khususnya dalam konteks $m$-commerce.

Implikasi manajerial penelitian ini adalah sebagai berikut. Kualitas layanan merupakan faktor penting yang perlu diperhatikan dan ditingkatkan oleh pelaku bisnis $m$-commerce karena memengaruhi pengalaman dan kepuasan pelanggan, dengan cara memberikan kualitas layanan yang baik dan unggul sesuai dengan yang diinginkan pelanggan. Selain itu, juga memperhatikan perceived risk yang terkandung pada 
aplikasi $m$-commerce karena memengaruhi kepuasan pelanggan. Yang perlu dilakukan m-commerce terhadap perceived risk adalah membuat pelanggan nyaman secara psikologis, mengeliminasi perasaan cemas dan ketegangan pelanggan karena kekhawatiran hilangnya data atau lainnya. Implikasi manajemen yang terakhir adalah meningkatkan pengalaman pelanggan karena berpengaruh terhadap kepuasan pelanggan. M-commerce dapat meningkatkan pengalaman pelanggan dengan cara membuat aplikasi yang user friendly, mudah digunakan dan menjual produk-produk yang menarik dan berbeda dengan yang ditawarkan oleh pesaing.

Keterbatasan penelitian ini adalah bahwa penelitian ini hanya memperlakukan kualitas layanan dan perceived risk sebagai dimensi tunggal tidak menggunakan multidimensi. Diharapkan pada penelitian selanjutnya mengimplemetasikan kualitas layanan dan perceived risk sebagai multidimensi agar mendapat perspektif yang lebih lengkap, melakukan penelitian pada masyarakat perkotaan lainnya, seperti kota Medan dan Surabaya dan menggunakan $m$ commerce lainnya seperti Tokopedia.

\section{DAFTAR PUSTAKA}

Appinventiv. (2020). Future of Mobile Commerce: Stats \& Trends to Know in 2020-2025. Retrieved February 1, 2020, from https://appinventiv.com/blog/mobilecommerce-trends-infographics/

Boo, H. V., Lee, N., \& Murray, D. (2014). Sports service quality for event venues: evidence from Malaysia. Sport, Business and Management: An International Journal, $4(2)$, $125-141$. https://doi.org/10.1108/SBM-11-2010-0020

Boon-itt, S. (2015). Managing self-service technology service quality to enhance e-satisfaction. International Journal of Quality and Service Sciences, 7(4), 373-391. https://doi.org/10.1108/IJQSS-01-2015-0013

Carù, A., \& Cova, B. (2003). Revisiting consumption experience: A more humble but complete view of the concept. Marketing Theory, 3(2), 267-286. https://doi.org/10.1177/14705931030032004

Chaney, D., Lunardo, R., \& Mencarelli, R. (2018). Consumption experience: past, present and future. Qualitative Market Research, 21(4), 402-420. https://doi.org/10.1108/QMR-04-2018-0042

Chang, E. C., \& Tseng, Y. F. (2013). Research note: E-store image, perceived value and perceived risk. Journal of Business Research, 66(7), 864-870. https://doi.org/10.1016/j.jbusres.2011.06.012

Chang, H. H., \& Chen, S. W. (2008). The impact of online store environment cues on purchase intention: Trust and perceived risk as a mediator. Online Information Review, 32(6), 818-841. https://doi.org/10.1108/14684520810923953

Chang, S. H., Chih, W. H., Liou, D. K., \& Yang, Y. T. (2016). The mediation of cognitive attitude for online shopping. Information Technology and People, 29(3), 618-646. https://doi.org/10.1108/ITP-082014-0172

Chen, X., \& Li, S. (2017). Understanding continuance intention of mobile payment services: An empirical study. Journal of Computer Information Systems, $57(4)$, 287-298. https://doi.org/10.1080/08874417.2016.1180649

Cronin, J. J., Brady, M. K., \& Hult, G. T. M. (2000). Assessing the effects of quality, value, and customer satisfaction on consumer behavioral intentions in service environments. Journal of Retailing, 76(2), 193-218. https://doi.org/10.1016/S00224359(00)00028-2

Forsythe, S., Liu, C. L., Shannon, D., \& Gardner, L. C. (2006). Devolopment of a scale to measure the perceived benefits and risks of online shopping. Journal of Interactive Marketing, 20(2), 55-75. https://doi.org/10.1002/dir

Forsythe, S. M., \& Shi, B. (2003). Consumer patronage and risk perceptions in Internet shopping. Journal of Business Research, 56(11), 867-875. https://doi.org/10.1016/S0148-2963(01)00273-9

Gentile, C., Spiller, N., \& Noci, G. (2007). How to Sustain the Customer Experience: An Overview of Experience Components that Co-create Value With the Customer. European Management Journal, 25(5), 395-410. https://doi.org/10.1016/j.emj.2007.08.005

Giannoulakis, C., Wang, C. H., \& Felver, N. (2015). A modeling approach to sport volunteer satisfaction. International Journal of Event and Festival Management, $\quad 6(3), \quad 182-199$. https://doi.org/10.1108/IJEFM-04-2014-0010

Gustafsson, A., Johnson, M. D., \& Roos, I. (2005). The Effects of Customer Satisfaction, Relationship Commitment Dimensions, and Triggers on Customer Retention. Journal of Marketing, 69(4), 210-218. https://doi.org/10.1509/jmkg.2005.69.4.210

Hair, J. F., Ringle, C. M., \& Sarstedt, M. (2011). PLS-SEM: Indeed a silver bullet. Journal of Marketing Theory and Practice, 19(2), 139-151. https://doi.org/10.2753/MTP1069-6679190202

Hair, J. F., Sarstedt, M., Ringle, C. M., \& Mena, J. A. (2012). An assessment of the use of partial least squares structural equation modeling in marketing research. Journal of the Academy of Marketing Science, 40(3), 414-433. https://doi.org/10.1007/s11747-011-0261-6

Heejun, P., \& Seung, B. (2007). Measuring service quality of online bookstores with WebQual. Jack, J.A. (Ed.), Human-Computer Interaction. HCI Applications and Services, Springer, Heidelberg, 4553 LNCS(PART 4), 95-103. https://doi.org/10.1007/978-3-54073111-5 12

Holbrook, M. B., \& Hirschman, E. C. (1982). The Experiential Aspects of Consumption: Consumer Fantasies, Feelings, and Fun. Journal of Consumer Research, 9(2), 132-140. https://doi.org/10.1086/208906

Khoo, S., Ha, H., \& McGregor, S. L. T. (2017). Service quality and student/customer satisfaction in the private tertiary education sector in Singapore. International Journal of Educational Management, 31(4), 430-444. https://doi.org/10.1108/IJEM-092015-0121

Kim, M. S., Shin, D. J., \& Koo, D. W. (2018). The influence of perceived service fairness on brand trust, brand experience and brand citizenship behavior. International Journal of Contemporary Hospitality Management, 30(7), 2603-2621. 
https://doi.org/10.1108/IJCHM-06-2017-0355

Klaus, P. \& Maklan, S. (2012). EXQ: A multiple-item scale for assessing service experience. Journal of Service Management, 23(1), 5-33. https://doi.org/10.1108/09564231211208952

Koetz, C. (2019). Managing the customer experience: a beauty retailer deploys all tactics. Journal of Business Strategy, 40(1), 10-17. https://doi.org/10.1108/JBS09-2017-0139

Kompas.com. (2018). Sejak Sepuluh Tahun Lalu, Perilaku Konsumen. Retrieved March 5, 2020, from https://ekonomi.kompas.com/read/2018/01/15/1640 37926/sejak-sepuluh-tahun-lalu-perilaku-konsumen

Kumar, V., Pozza, I. D., \& Ganesh, J. (2013). Revisiting the satisfaction-loyalty relationship: Empirical generalizations and directions for future research. Journal of Retailing, 89(3), 246-262. https://doi.org/10.1016/j.jretai.2013.02.001

Lainamngern, S., \& Sawmong, S. (2019). How customer relationship management, perceived risk, perceived service quality, and passenger trust affect a fullservice airline's passenger satisfaction. Journal of Business \& Retail Management Research, 13(03), 160-177. https://doi.org/10.24052/jbrmr/v13is03/art-15

Laukkanen, T., \& Kiviniemi, V. (2010). The role of information in mobile banking resistance. International Journal of Bank Marketing, 28(5), 372-388. https://doi.org/10.1108/02652321011064890

Levy, M., Weitz, B. ., \& Grewal, D. (2015). Retail Management (9th ed.). New York: McGraw- Hill Education.

Liao, C., Lin, H. N., \& Liu, Y. P. (2010). Predicting the use of pirated software: A contingency model integrating perceived risk with the theory of planned behavior. Journal of Business Ethics, 91(2), 237-252. https://doi.org/10.1007/s10551-009-0081-5

Lin, Y., Luo, J., Cai, S., Ma, S., \& Rong, K. (2016). Exploring the service quality in the e-commerce context: A triadic view. Industrial Management and Data Systems, 116(3), 388-415. https://doi.org/10.1108/IMDS-04-2015-0116

Littler, D., \& Melanthiou, D. (2006). Consumer perceptions of risk and uncertainty and the implications for behaviour towards innovative retail services: The case of Internet Banking. Journal of Retailing and Consumer Services, 13, 431-443.

Mahapatra, S. (2017). Mobile shopping among young consumers: an empirical study in an emerging market. International Journal of Retail \& Distribution Management, IJRDM-08-2016-0128. https://doi.org/10.1108/IJRDM-08-2016-0128

Mbama, C. I., \& Ezepue, P. O. (2018). Digital banking, customer experience and bank financial performance: UK customers' perceptions. International Journal of Bank Marketing, 36(2), 230-255. https://doi.org/10.1108/IJBM-11-2016-0181

Meuter, M. L., Ostrom, A. L., Bitner, M. J., \& Roundtree, R. (2003). The influence of technology anxiety on consumer use and experiences with self-service technologies. Journal of Business Research, 56(11), 899-906. https://doi.org/10.1016/S01482963(01)00276-4

Meyer, C., \& Schwager, A. (2007). Understanding customer experience. Harvard Business Review, February, 117-126.
Mohd-Ramly, S., \& Omar, N. A. (2017). Exploring the influence of store attributes on customer experience and customer engagement. International Journal of Retail and Distribution Management, 45(11), 11381158. https://doi.org/10.1108/IJRDM-04-2016-0049

Nguyen, Q., Nisar, T. M., Knox, D., \& Prabhakar, G. P. (2018). Understanding customer satisfaction in the UK quick service restaurant industry: The influence of the tangible attributes of perceived service quality. British Food Journal, 120(6), 1207-1222. https://doi.org/10.1108/BFJ-08-2017-0449

Oliver, R. L. (1980). A Cognitive Model of the Antecedents and Conseqences of Satisfaction Decisions. Journal of Marketing Research (JMR), 17(4), 460-469.

Otto, J. E., \& Ritchie, J. R. B. (1996). The service experience in tourism. Tourism Management, 17(3), 165-174. 5177(96)00003-9

Pine II, J. B., \& Gilmore, J. H. (2000). Satisfaction, sacrifice, surprise: three small steps create one giant leap into the experience economy. Strategy \& Leadership, 28(1), 18-23.

Pizam, A., Shapoval, V., \& Ellis, T. (2016). Customer satisfaction and its measurement in hospitality enterprises: a revisit and update. International Journal of Contemporary Hospitality Management, 28(1), 2-35. https://doi.org/10.1108/IJCHM-042015-0167

Poromatikul, C., De Maeyer, P., Leelapanyalert, K., \& Zaby, S. (2020). Drivers of continuance intention with mobile banking apps. International Journal of Bank Marketing, 38(1), 242-262. https://doi.org/10.1108/IJBM-08-2018-0224

Rahman, M. S., Mannan, M., Hossain, M. A., \& Zaman, M. H. (2018). Patient's behavioral intention: public and private hospitals context. Marketing Intelligence and Planning, 36(3), 349-364. https://doi.org/10.1108/MIP-08-2017-0155

Rajaguru, R. (2016). Role of value for money and service quality on behavioural intention: A study of full service and low cost airlines. Journal of Air Transport Management, 53, 114-122. https://doi.org/10.1016/j.jairtraman.2016.02.008

Roy, S., Sreejesh, S., \& Bhatia, S. (2019). Service quality versus service experience : An empirical examination of the consequential effects in B2B services. Industrial Marketing Management, (February 2019). https://doi.org/10.1016/j.indmarman.2019.02.017

Santos, J. (2003). E-service quality: a model of virtual service quality dimensions. Managing Service Quality, 13(3), 233-246. https://doi.org/10.1108/09604520310476490

Shahijan, M. K., Rezaei, S., \& Amin, M. (2018). Qualities of effective cruise marketing strategy: Cruisers' experience, service convenience, values, satisfaction and revisit intention. International Journal of Quality and Reliability Management, 35(10), 2304-2327. https://doi.org/10.1108/IJQRM-07-2017-0135

Sharma, N., \& Patterson, P. G. (2000). Switching costs, alternative attractiveness and experience as moderators of relationship commitment in professional, consumer services. International Journal of Service Industry Management, 11(5), 470-490. https://doi.org/10.1108/09564230010360182

Suhartanto, D., Brien, A., Sumarjan, N., \& Wibisono, N. (2018). Examining attraction loyalty formation in 
creative tourism. International Journal of Quality and Service Sciences, 10(2), 163-175. https://doi.org/10.1108/IJQSS-08-2017-0068

Tandon, U., Kiran, R., \& Sah, A. N. (2018). The influence of website functionality, drivers and perceived risk on customer satisfaction in online shopping: an emerging economy case. Information Systems and $E$ Business Management, 16(1), 57-91. https://doi.org/10.1007/s10257-017-0341-3

Trivedi, R., \& Jagani, K. (2018). Perceived service quality, repeat use of healthcare services and inpatient satisfaction in emerging economy: Empirical evidences from India. International Journal of Pharmaceutical and Healthcare Marketing, 12(3), 288-306. https://doi.org/10.1108/IJPHM-11-20170065

Turki, H., \& Amara, D. (2017). Toward a better understanding of experience during trips: impact on satisfaction, destination attachment and word-ofmouth. International Journal of Tourism Cities, 3(4), 466-482. https://doi.org/10.1108/IJTC-10-20160038

Tzavlopoulos, I., Gotzamani, K., Andronikidis, A., \& Vassiliadis, C. (2019). Determining the impact of e- commerce quality on customers' perceived risk, satisfaction, value and loyalty. International Journal of Quality and Service Sciences, 11(4), 576-587. https://doi.org/10.1108/IJQSS-03-2019-0047

Wirtz, J., \& Lovelock, C. (2018). Esssentials of Service Marketing (3rd ed.). England: Pearson Education Limited.

Wong, K. K.-K. (2013). Partial Least Squares Structural Equation Modeling (PLS-SEM) Techniques Using SmartPLS. Marketing Bulletin, 24(1), 1-32. Retrieved from http://marketingbulletin.massey.ac.nz/v24/mb_v24_t1_wong.pdf\%5 Cnhttp://www.researchgate.net/profile/Ken_Wong1 0/publication/268449353_Partial_Least_Squares_St ructural_Equation_Modeling_(PLS-

SEM)_Techniques_Using_SmartPLS/links/54773b1 b0cf293e2da25e3f3.pdf

Wu, H.-C. (2014). The effects of customer satisfaction, perceived value, corporate image and service quality on behavioral intentions in gaming establishments. Asia Pacific Journal of Marketing and Logistics, 26(4), 540-565. 